\title{
A Study on Biomarkers in a Spatially Distributed Type - 2 Diabetes mellitus Groups in Southern Tamil Nadu, India
}

\author{
*Murugan.A \\ Associate Professor and HOD of Zoology, S.T. Hindu College, Nagercoil, Kanyakumari District, T.N, India. \\ Beula.A., Research student.
}

\begin{abstract}
Diabetes, a dreaded disease already ravaged a huge population worldwide, whether it is inherited through generations or invited by the people by their uncontrolled way of life is still obscure. Biomarkers assay is a boon to the diseased to opt proper prophylactic measures to curb or eradicate diseases. The elevated levels of various biomarkers related to inflammation of vital organs, liver function, kidney function and other vital parameters in our diabetic cases reveals the extent of organ(s) damage in these subjects. It is also evident that the levels of various biomarkers are similar in our diabetic subjects, irrespective of their habits or habitats.
\end{abstract}

Keywords: alanine aminotransferase, aspartate aminotransferase, blood urea nitrogen, gammaglutamyl transferase, glycated haemoglobin.

\section{Introduction}

Diabetes, a multifactorial disease due to deficiency or diminished effectiveness of endogenous insulin. There is no cure for this dreaded disease, but with proper management the diseased can lead a normal life.

Abnormal high blood sugar resulting from the insufficient levels of insulin evokes disordered metabolism in the diseased subjects ${ }^{1}$. It produces acute complications like ketoacidosis and nonketotic hyperosmolar coma ${ }^{2}$ and serious long-term complications such as cardiovascular diseases, stroke, chronic kidney problems, even failure of kidney, and also can cause damage to the eyes ${ }^{3}$.

Biomarker is a characteristic that is objectively measured and evaluated as an indicator of normal biological processes, pathogenic processes or pharmacological responses to a therapeutic intervention ${ }^{4}$. Biomarker assays gives useful information about the levels of these substances in the patients and pave ways to curb or eradicate disease(s).

The present study tries to explore the extent of damage caused by diabetes and its related complications by the way of analyzing certain vital biomarkers in the selected cases of spatially distributed population in Kanya kumari District, Tamil Nadu, India.

\section{Materials and methods}

The present study is undertaken in high range, midland and coastal areas of Kanyakumari District, Tamil Nadu, the Southern landmark of India ${ }^{5}$. The study population includes Kaani tribe (Scheduled Tribe-high range community) ${ }^{6,7}$, Nadar (Backward Community-Midland settlers) ${ }^{8}$, Nair (Forward Community-Midland settlers) ${ }^{9}$ and Mukkuvar (Most Backward Community-Coastal population) ${ }^{10}$.

The study consists of 4 ST male and 4 female diabetics (experimental group) and equal number of nondiabetics (control group) in both sexes, 8 male and 8 female diabetics and same number of non-diabetics in both Nadar and Mukkuvar communities and 10 males and females each in both diabetic and non-diabetic groups in Nair community.

Diabetics are screened by the method described elsewhere ${ }^{11}$ and priorities have been given to human values during the collection of samples. For the collection of blood and urine samples well trained staff nurses are used. Standard methods are used for the estimation of blood sugar (fasting and post-prandial) ${ }^{12}$, serum insulin $^{13}, \mathrm{C}_{\text {-peptide }}{ }^{14}, \mathrm{HbA}_{1} \mathrm{C}^{15}, \mathrm{C}$-reactive protein ${ }^{16}$, ferritin ${ }^{17}, \mathrm{IgG}^{18}{ }^{2}$ in (urine), $\operatorname{IgM}^{19}$ (inurine), TSH, $\mathrm{fT}_{3}, \mathrm{fT}_{4}$, $\mathrm{TT}_{3}$ and $\mathrm{TT}_{4}^{20-22}$, cholesterol ${ }^{23}, \mathrm{Tg}^{24}$, LDL-C, VLDL-C and HDL-C ${ }^{25}, \mathrm{ALP}^{26}, \mathrm{LDH}^{27}, \mathrm{GGT}^{28}, \mathrm{AST}^{29}, \mathrm{ALT}^{30}$, bilirubin (total) ${ }^{31}, \mathrm{BUN}^{32}$, creatinine ${ }^{33}$, albumin (in urine) $)^{34}$, creatine kinase ${ }^{35}, \mathrm{ChE}^{36}$ and amylase ${ }^{37}$. Statistical analysis are made with SPSS statistical package $(\text { Version }-11)^{38}$.

\section{Results}

Some of the vital parameters in serum and urine samples of the selected diabetics and non-diabetics are given in table 1. It is evident from the table that, except insulin a significant level of increase of serum sugar (fasting and post-prandial), $\mathrm{C}$-peptide, $\mathrm{HbA}_{1} \mathrm{C}$, $\mathrm{C}$-reactive protein, ferritin, Ig-Gas well as Ig-M in urine samples are observed in the selected male and female diabetic cases than their respective non-diabetics.

Thyroid profile study revealed that, there is an altered level of TSH, $\mathrm{fT}_{3}, \mathrm{fT}_{4}, \mathrm{TT}_{3}$ and $\mathrm{TT}_{4}$ in diabetics than their non-diabetic counterparts and the values are statistically highly significant $(\mathrm{p}=<0.01)$. Studies on 
lipid profile showed except HDL-C, an enhanced level of cholesterol, Tg, LDL-C and VLDL-C in diabetics of both sexes than their respective controls $(\mathrm{p}=<0.01)$ (table .2 ).

An elevated level of serum ALP, LDH, GGT, AST, ALT, creatine kinase, ACP and amylase and a decrease of lipase is detected in diabetic subjects than their non-diabetic controls. A high level of serum BUN, creatinine and albumin are also observed in diabetics than their respective non-diabetics $(p=<0.01)$ (table.3.).

\section{Discussion}

Diabetes, a monster which devastates the global community at an alarming rate. It's hereditary as well as non-hereditary origin stunned the mankind and the global community is handicapped to eliminate this disease in this modern day also. The surge of this disease is a new threat and challenge to the modern world. The disease has already swallowed a sizeable number of human population in almost all the continents of the world barring from age, sex, race, religion or region.

Diabetes prevalence is a global scenario ${ }^{39,40}$ and it is considered as one of the potential causes of death and disability in the entire world ${ }^{41}$. A statistically significant low level of insulin ${ }^{1}$ is followed by higher level of fasting and post-prandial sugar and high level of $\mathrm{Hb} \mathrm{A}_{1} \mathrm{C}^{42}$ is common among diabetics. Our study too supports this view.A high level of inflammatory markers such as C-peptide ${ }^{43,44}$ and C-reactive protein ${ }^{45,46}$ and ferritin ${ }^{47,48}$ an acute phase protein in diabetics are reported by earlier reports and it is true in our study also $(\mathrm{p}=<0.01)$.

Previous studies revealed that elevated levels of urinary markers such as $\operatorname{IgG}^{49}$ and $\operatorname{IgM}^{50}$ and albumin ${ }^{51}$ is an impairment of kidney function. An altered levels of $\mathrm{IgG}, \mathrm{IgM}$ and albumin is observed in our diabetic subjects $(\mathrm{p}=<0.01)$. A high level of $\mathrm{BUN}^{52}$ and serum creatinine $\mathrm{s}^{52,53}$ is an indicator of kidney dysfunction. An enhanced levels of BUN and creatinine noticed in our diabetics $(p=<0.01)$ showed that they are at the risk of renal dysfunction.

Earlier reports say high levels of serum $\mathrm{ALT}^{54}, \mathrm{AST}^{52}, \mathrm{ALP}^{55}, \mathrm{GGT}^{56}, \mathrm{LDH}^{52}$ and bilirubin (total) ${ }^{54}$ reveal liver problems. A statistically significant increased levels of these substances are noticed in our diabetic cases than their respective controls $(\mathrm{p}=<0.01)$. Clinical hypothyroidism in diabetics are reported bymany researchers ${ }^{57,58}$ and a marked level of increase of $\mathrm{TSH}, \mathrm{fT}_{3}, \mathrm{fT}_{4}, \mathrm{TT}_{3}$ and $\mathrm{TT}_{4}$ are observed in our diabetic subjects of both sexes than their respective counterparts $(\mathrm{p}=<0.01)$.

Abnormalities in lipid profile is one of the common complications in diabetes mellitus ${ }^{59,60}$. A noticeable level of increase of cholesterol, triglyceride (Tg), low density lipoprotein cholesterol (LDL-C) and very low density lipoprotein cholesterol (VLDL-C) and decrease of high density lipoprotein cholesterol (HDLC) is observed in our diabetics than their respective controls $(p=<0.01)$. Reports say enhanced levels of amylase $^{61}$, creatine kinase ${ }^{62}$ and choline esterae ${ }^{63}$ are associated with heart disease in diabetic subjects. A similar higher levels of these marker enzymes are detected in our diabetic cases than their respective controls $(\mathrm{p}=<0.01)$.

\section{Conclusion}

Biomarkers assay gives valid information about the extent of the damage caused by diabetes, which is useful to take solid measures for effective management strategies to control diabetes for the sake of human health and welfare. A remarkable level of increase of almost all the selected biomarkers reveals the organ(s) damage in the diseased and it paves way to the patients to opt better treatments to reduce and/or avoid further complications, however large scale studies are imminent to curb the disease related complications.

If the present alarming rate of increase of diabetes will prevail in the future, there will be no normal persons at one stage. If you want to escape from the clutches of this deadliest demon, try to be a good follower nor than a preacher of good ideals. The present study confirmed that both habits and habitats are having no role on diabetic complications, which is brought to light by the similar way of expression of some of the selected biomarkers in the patients.

We need not accumulate amassing wealth to our future generations, but we have to transfer healthy germplasm which is utmost important and it is the need of the hour and the future as well.

\section{Acknowledgement}

The support and co-operation extended by our study groups is highly acknowledged. Thanks are due to University Grants Commission, New Delhi, for financial support.

\section{References}

[1]. Tierney L.M., Mc Phee SJ and Papadakis MA. 2002. In: Current medical diagnosis and treatment, International edition. Lange Medical Books, McGraw Hill, New York:1203-15.

[2]. Kitabchi AE., Umpierrez GE., Miles JM and Fisher JN.2009. Hyperglycemic crisis in adult patients with diabetes. Diabetes care; 32(7) :1335-43.

[3]. WHO. 2013. Diabetes Fact Sheet, No. 312.

[4]. Kyle S and Tavel JA.2010. What are biomarkers? Curr. Opin.HIV/AIDS:5(6) : 463-66. 
A Study on Biomarkers in a Spatially Distributed Type - 2 Diabetes mellitus Groups in Southern ..

[5]. www.en.wikipedia.org/wiki/kanyakumari_district

[6]. Shajeela PS., Mohan VR and Jesudas L.2010. Medicinal Plants used by the Kaanikars of Kanyakumari district, Tamil Nadu. Asian J. Exp. Biol.Sci; 1(3) : 624-26.

[7]. Ayyanar M. 2010. Ethnographic profile of Kannitribals, an oldest group of ethinic communities of Southern India. Afro Asian J. Anthropol. Social Policy; 1(2) : 109-19.

[8]. Jeeva S and Femila V. 2012. Ethnobotanical investigation of Nadars in Aloor village, Kanyakumari district, Tamil Nadu, India. Asian Pacific J.Trop.Biomed; S593-600.

[9]. www.historyof nairs.blogspot.in2009/08 history of -nairs-community-from-Kerala.html

[10]. Thurston E.1987. Castes and Tribes of South India.Vol V., edited by K. Rangachari, Asian Educational service, New Delhi.

[11]. 77 Electronica Ltd, 1116 Budapest, Hungary.

[12]. Trinder P. 1969. Blood safety and clinical technology, guidelines on standard operating procedures for clinical chemistry. Ann. Clin. Biochem; 6:24.

[13]. Kao PC., Taylor RL and Service FC. 1994. Proinsulin by immunochemiluminometric assay for the diagnosis of insulinoma. J. Clin. Endocrinol. Metab; 78: 1048-51.

[14]. Rendell M.1983. C-peptide levels as a criterian in treatment of maturity onset diabetes. J.Clin. Endocrinol. Metab; 57(6) : 1198.

[15]. Bry L., Chen PC and Sacks DB. 2001. Effects of haemoglobin variants and chemically modified derivatives on assays for glycohaemoglobin. Clin. Chem; 47:153-63.

[16]. Ridker PM., Hennekens CH., Buring JE and Rifai N. 2000. C-reactive protein and other markers of inflammation in the prediction of cardiovascular disease in women. New Eng. J. Med; 342(12) : 836-43.

[17]. Addison GM., Beamish MR., Hales CN, Hodgkins M., Jacobs A and Llewellin P.1972. An immunoradiometric assay for ferritin in the serum of normal subjects and patients with iron deficiency and iron overload. J.Clinc. Pathol; 25(4) : 326-29.

[18]. Ritchie RF., Alper CA., Graves J., et al. 1973. Automated quantitation of proteins in serum and other biological fluids.Am.J.Clin.Pathol;59:151-59,

[19]. Dittmar D., Cleary TJ and Castro A. 1979. Immunoglobulin G and M specific enzyme linked immunosorbent assay for detection of dengue antibodies. J.Clin. Microbiol; 9(4) : 498-502.

[20]. Chopra IJ., Soloman DH and Ho RS. 1971. A radioimmunoassay of thyroxine. J. Clin. Endocrinol; 33:865-69.

[21]. Young DS., Pastner LC and Giberman U. 1975. Effects of drugs on clinical laboratory tests. Clin. Chem.; 21:3660.

[22]. Caldwell $\mathrm{G}$ et al.1985. A new strategy for thyroid function. Lancet; 1: 117.

[23]. Ellefson RD and Caraway WT. 1976. Lipids and Lipoproteins; In : Tietz NW., Fundamentals of Biochemistry $\left(2^{\text {nd }}\right.$ edn), WB Saunders, Philadelphia : 474-538.

[24]. Bucolo G and David H. 1973. Quantitative determination of serum triglycerides by the use of enzymes. Clin.Chem; 19(5) : 476-82.

[25]. Stockigt JR.2001. Free thyroid hormone measurement: A critical appraisal. Endocrinol. Metab. Clin. N.Am; 30:265-89.

[26]. Johnson AM., Rohlfs EM and Silverman LM. 1999. In : Tietz NW., Text book of clinical chemistry ( $3^{\text {rd }}$ edn), Burtis CA and Ashwood ER (edn). WB Saunders, Philadelphia : 477-540, 676-689.

[27]. $\quad$ Moss P and Henderson AR. 1999. In : Clinical enzymology ( $3^{\text {rd }}$ edn), WB Saunders, Philadelphia : 617-721.

[28]. Szasz G. 1974. In : Methods of enzymatic analysis 2cde edn $2: 715$

[29]. Expert Panel of the IFCC on enzymes.1976. Clin. Chem. Acta : 70; F19.

[30]. Bradley DW., Maynard JE., Emery G and Webster H. 1972. Transaminase activities in serum of long-term hemodialysis patients. Clin. Chem; 18(12) : 1442.

[31]. Pearlman FC and Lee RT. 1974. Detection and measurement of total bilirubin in serum with the use of surfactants as solubilising agents. Clin. Chem; 20(4) : 447-53.

[32]. Young DS. 1990. In : Effect of preanalytical variables on clinical laboratory tests $\left(2^{\text {nd }}\right.$ edn $)$, AACC press, Washington : 4-489.

[33]. Young DS.1990. In : Effects of drugs on clinical laboratory tests ( $3^{\text {rd }}$ edn), AACC Press, Wadhington : 21.5.

[34]. Hallbach J., Hoffman GE and Guder WG.1991. Over estimation of albumin in heparinised plasma. Clin. Chem; 37(4) : 566-68

[35]. Hughes BP. 1962. A method for the estimation of serum creatine kinase and its use in comparing creatine kinase and aldolase activity in normal and pathological sera. Clin. Chem. Acta; 7: 597-603.

[36]. King J. 1974. Cholinesterase in Clinical Biochemistry Edited by Curtius HC and Marc Roth. DeGruyter W. Berlin and New York : 1161.

[37]. www.tekisimizanaliz.com

[38]. Burtis CA., Ashwood ER and Burns DE. 2012. Tietz text book of clinical chemistry and molecular diagnostics (5 ${ }^{\text {th }}$ edn) Elsevier ; 583-87.

[39]. Huizinga MM and Rothman RL.2006. Addressing the diabetic pandemic : A comprehensive approach.Ind.J.Med. Res; 124: 481-84

[40]. Wild S., Roglic G., Green A., et al. 2004. Global prevalence of diabetes : Estimates for the year 2000 and projections for 2030. Diabetes Care; 27: 1047-53.

[41]. King H., Aubert RE and Herman WH. 1998. Global burden of diabetes 1995-2025: prevalence, numerical estimates and projections. Diabetes Care; 21: 481-84.

[42]. Genuth S. 2006. Insights from the diabetes control and complications trial/epidemiology of diabetes interventions and complications study on the use of intensive glycaemic treatment to reduce the risk of complications of type-1 diabetes. Endocr. Pract 12; (Suppl:1) :34-41.

[43]. Hales CN and Parker DJP. 1992. T2DM : the thrifty phenotype hypothesis. Diabetologia; 35(7) 595-601.

[44]. Neufeld ND., Raffel LJ., Landon C., et al. 1998. Early presentation of Type -2 diabetes in Mexican - American youth. Diabetes Care; 21(1) 80-86.

[45]. Dehghan A., Kardys I., de Maat MP., et al. 2007. Genetic variation, C-reactive protein levels and incidence of diabetes. Diabetes; 56(3) : 872-78.

[46]. Pepys MB and Hirschfield CM. 2003. C-reactive protein : A critical update. J. Clin. Invest; 111(12) 1805-12.

[47]. Eshed I., Elis A and Lishner M. 2001. Plasma ferritin and Type-2 Diaetes mellitus : A critical review. Endocrinol. Res; 27(1-2) : 91 107.

[48]. Theil E. 1987. Ferritin : structure, gene regulation and cellular function in animals, plants and microorganisms. Ann. Rev. Biochem; 56(1) : 289-315.

[49]. Narita T., Hosoba M., Kakei M., et al.2006. Increased urinary excretions of IgG, ceruloplasmin and transferrin predict development of mciroalbuminuria in patients with Type-2 diabetes. Diabetes Care; 29:142-44.

[50]. Bakoush O., Tencer J., Tapia J., et al. 2002. Higher urinary IgM excretion in Type -2 diabetic nephropathy compare to Type-2 diabetic nephropathy. Kidney Int; 61:203-08. 
A Study on Biomarkers in a Spatially Distributed Type - 2 Diabetes mellitus Groups in Southern ..

[51]. Remuzzi A., Viberti GC., Ruggenenti P., et.al.1990. Glomerular response to hyperglycemia in human diabetic nephropathy. Am. J. physiol; 259: F545-52.

[52]. Murugan A and Jerlin Nirmala F.2012. Evaluation of some prominent biomarkers in rural Type-2 Diabetes mellitus cases in Kanyakumari District, Tamil Nadu, India. World Aca. Sci. Engineer. Tech; $70: 206-09$.

[53]. Singh TP., Singh AD and Singh TB. 2001.Prevalence of Diabetes mellitus in Manipur. In : SK. Shah (editor). Diabetes update : Guwahati, North Eastern Diabetes Society : 13-19.

[54]. Harris EH. 2005. Elevated liver function tests in Type-2 diabetes. Clin. Diabet; 23(3) : 115-19.

[55]. Li-Fern H and Rajasoorya C.1999. The elevated serum ALP-the chase that led to two endocrinopathies and one possible unifying diagnosis. E.J. Endocrinol; 140(2) : 143-47.

[56]. Betro MG., On RC and Edwards JB. 1973. Gamma glutamyl transpeptidase in diseases of the liver and bone. Am.J.Clin. Pathol;60(5): 672-78.

[57]. Tunbridge WMG., Evered DC., Hall R., et al. 1997. Spectrum of thyroid disease in community-Whickham Survey. Clin. Endocrinol; 19: 481-93.

[58]. Khan A., Khan MA and Aktar S.2002. Thyroid disorders, etiology and prevalence. J. Med. Sci; 2: 89-94.

[59]. Gandhi HR.2001. Diabetes and coronary artery disease : Importance of risk factors. Cardiol. Today; $1: 31-34$

[60]. Ravi K., Rajasekaran S and Subramanian S. 2005. Antihyperlipidemic effect of Eugenia jambolana seed kernel on streptozotocin induced diabetes in rats. J.Pharmacol; 560: 201-05.

[61]. Larsen ML., Horder M and Mongensen EF.1990. Effect of long-term monitoring of glycosylated haemoglobin levels in insulindependent Diabetes mellitus. N. Eng. J.Med; 323(15) : 1021-25.

[62]. Jevric-Causevic A., Malenica M and Dujic T. 2006. Creatine kinase activity in patients with Diabetes mellitus type I and type II. Bosn. J. Basic Med.Sci; 6(3) : 5-9.

[63]. Toman R., Zeman V and Hanika J. 1981. Prevalence of diabetes in Northern India. Prakt. Lek; 61:856-61.

Table.1. shows some of the important parameters in serum/urine samples of the selected diabetics and nondiabetics.

( $n=120$ cases; 30 male +30 female diabetics; 30 male +30 female non-diabetics; values are \pm SD)

\begin{tabular}{|c|c|c|c|c|}
\hline \multirow[t]{2}{*}{ Parameters } & \multicolumn{2}{|l|}{ Male } & \multicolumn{2}{|l|}{ Female } \\
\hline & Non-diabetics & Diabetics & Non-diabetics & Diabetics \\
\hline$*$ Sugar $(\mathrm{F})^{1}$ & $82.15 \pm 10.36$ & $142.66 \pm 9.85$ & $83.44 \pm 7.55$ & $143.75 \pm 16.71$ \\
\hline$*$ Sugar $(\mathrm{PP})^{2}$ & $103.45 \pm 6.84$ & $175.92 \pm 5.25$ & $108.45 \pm 4.31$ & $182.75 \pm 10.6$ \\
\hline$*$ Insulin ${ }^{3}$ & $34.3 \pm 0.61$ & $15.3 \pm 2.1$ & $33.9 \pm 1.79$ & $17.65 \pm 2.15$ \\
\hline$*$ C-peptide ${ }^{4}$ & $0.42 \pm 0.2$ & $1.06 \pm 0.13$ & $0.54 \pm 0.1$ & $1.06 \pm 0.07$ \\
\hline$* \mathrm{Hb} \mathrm{A}_{1} \mathrm{C}^{5}$ & $5.08 \pm 0.4$ & $8.37 \pm 1.7$ & $5.12 \pm 0.54$ & $8.4 \pm 1.4$ \\
\hline$*$ C-reactive protein ${ }^{6}$ & $0.42 \pm 0.06$ & $0.55 \pm 0.05$ & $0.41 \pm 0.04$ & $0.57 \pm 0.07$ \\
\hline${ }^{*}$ Ferritin $^{7}$ & $46.95 \pm 4.51$ & $296.02 \pm 35.7$ & $49.52 \pm 5.2$ & $307.69 \pm 41.75$ \\
\hline$* \operatorname{IgG}^{8}$ (urine) & $1480 \pm 46$ & $1865 \pm 62$ & $1498 \pm 54$ & $1908 \pm 78$ \\
\hline$* \operatorname{IgM}^{9}$ (urine) & $104.33 \pm 4.61$ & $170.5 \pm 12.1$ & $103.7 \pm 5.1$ & $172.5 \pm 9.43$ \\
\hline
\end{tabular}

(Units : $\mathrm{mg} / \mathrm{dl}^{1,2,8,9}, \mu \mathrm{l} / \mathrm{ml}^{3}, \mathrm{ng} / \mathrm{ml}^{4,7}, \%^{5}, \mathrm{mg} / \mathrm{l}^{6}$,

$\mathrm{t}$ values : diabetics vs non-diabetics, $\mathrm{p}=<0.01$-highly significant*)

Table.2. reveals thyroid and lipid profiles in serum of the selected diabetics and non-diabetics.

$(\mathrm{n}=120$ cases; 30 male +30 female diabetics; 30 male +30 female non-diabetics; values are \pm SD)

\begin{tabular}{|c|c|c|c|c|}
\hline \multirow[t]{2}{*}{ Parameters } & \multicolumn{2}{|l|}{ Male } & \multicolumn{2}{|l|}{ Female } \\
\hline & Non-diabetics & Diabetics & Non-diabetics & Diabetics \\
\hline$* \mathrm{TSH}^{1}$ & $2.08 \pm 0.12$ & $3.91 \pm 0.14$ & $2.27 \pm 0.11$ & $4.1 \pm 0.21$ \\
\hline$*_{\mathrm{f}} \mathrm{T}_{3}{ }^{2}$ & $2.15 \pm 0.1$ & $2.94 \pm 0.12$ & $2.29 \pm 0.13$ & $3.17 \pm 0.09$ \\
\hline$*_{\mathrm{fT}}{ }^{3}$ & $0.82 \pm 0.03$ & $0.92 \pm 0.04$ & $0.79 \pm 0.04$ & $0.99 \pm 0.02$ \\
\hline$*$ Total $_{3}{ }^{4}$ & $0.66 \pm 0.05$ & $0.94 \pm 0.02$ & $064 \pm 0.01$ & $0.97 \pm 0.05$ \\
\hline$*$ Total $\mathrm{T}_{4}{ }^{5}$ & $6.49 \pm 0.27$ & $7.94 \pm 0.31$ & $6.4 \pm 0.21$ & $8.11 \pm 0.3$ \\
\hline${ }^{*}$ Cholesterol $^{6}$ & $188.3 \pm 20.61$ & $214.23 \pm 44.72$ & $197.2 \pm 38.75$ & $229.73 \pm 57.44$ \\
\hline$* \mathrm{Tg}^{7}$ & $160.57 \pm 19.72$ & $211.53 \pm 22.6$ & $178.03 \pm 27.32$ & $242 \pm 29.54$ \\
\hline${ }^{*} \mathrm{LDL} \mathrm{C}^{8}$ & $103.77 \pm 7.47$ & $138.2 \pm 9.41$ & $121.37 \pm 8.7$ & $155.53 \pm 9.4$ \\
\hline$*$ VLDL-C $^{9}$ & $24.57 \pm 4.1$ & $28.77 \pm 3.11$ & $22.67 \pm 3.3$ & $23.67 \pm 3.25$ \\
\hline$* \mathrm{HDL}-\mathrm{C}^{10}$ & $46.23 \pm 3.3$ & $43.93 \pm 1.02$ & $48.9 \pm 3.21$ & $44.21 \pm 1.62$ \\
\hline
\end{tabular}

(Units : $\mu \mathrm{lu} / \mathrm{ml}^{1}, \mathrm{pg} / \mathrm{ml}^{2}, \mathrm{ng} / \mathrm{dl}^{3}{ }^{3} \mathrm{ng} / \mathrm{ml}^{4}, \mu \mathrm{g} / \mathrm{dl}^{5}, \mathrm{mg} / \mathrm{dl}^{6-10}$,

$\mathrm{t}$ values : diabetics vs non-diabetics, $\mathrm{p}=<0.01$-highly significant*) 
A Study on Biomarkers in a Spatially Distributed Type - 2 Diabetes mellitus Groups in Southern ..

Table.3. explains some of the selected biomarkers in the serum and urine samplesdiabetics and non-diabetics. $(\mathrm{n}=120$ cases; 30 male +30 female diabetics; 30 male +30 female non-diabetics; values are \pm SD)

\begin{tabular}{|c|c|c|c|c|}
\hline \multirow[t]{2}{*}{ Parameters } & \multicolumn{2}{|l|}{ Male } & \multicolumn{2}{|l|}{ Female } \\
\hline & Non-diabetics & Diabetics & Non-diabetics & Diabetics \\
\hline$* \mathrm{ALP}^{1}$ & $181.1 \pm 7.2$ & $259.3 \pm 7.3$ & $190.4 \pm 9.12$ & $261.7 \pm 5.71$ \\
\hline$* \mathrm{LDH}^{2}$ & $363.4 \pm 11.3$ & $435.6 \pm 8.11$ & $373.8 \pm 4.9$ & $448.7 \pm 17.13$ \\
\hline$* \mathrm{GGT}^{3}$ & $22.9 \pm 3.5$ & $35.3 \pm 1.9$ & $24.6 \pm 3.1$ & $34.87 \pm 4.15$ \\
\hline$* \mathrm{AST}^{4}$ & $29.41 \pm 1.7$ & $41.43 \pm 2.2$ & $28.1 \pm 2.4$ & $42.5 \pm 1.91$ \\
\hline$* \mathrm{ALT}^{5}$ & $31.61 \pm 0.97$ & $40.3 \pm 1.51$ & $33.53 \pm 1.81$ & $41.91 \pm 1.52$ \\
\hline$*$ Bilirubin $^{6}$ (total) & $0.7 \pm 0.04$ & $0.88 \pm 0.12$ & $0.72 \pm 0.13$ & $0.92 \pm 0.2$ \\
\hline$* \mathrm{BUN}^{7}$ & $9.92 \pm 1.21$ & $19.57 \pm 2.51$ & $9.89 \pm 1.33$ & $19.15 \pm 1.59$ \\
\hline${ }^{*}$ Creatinine $^{8}$ & $0.73 \pm 0.03$ & $1.05 \pm 0.02$ & $0.75 \pm 0.06$ & $1 \pm 0.09$ \\
\hline *Albumin (urine) & $24.9 \pm 1.9$ & $53.8 \pm 4.47$ & $25.6 \pm 2.71$ & $52.5 \pm 3.77$ \\
\hline${ }^{*}$ Creatine kinase ${ }^{10}$ & $6.1 \pm 0.86$ & $10.02 \pm 1.3$ & $6 \pm 0.09$ & $10.45 \pm 0.9$ \\
\hline$* \mathrm{ChE}^{11}$ & $7003 \pm 302$ & $8408 \pm 161$ & $7127 \pm 128$ & $8065 \pm 152$ \\
\hline$*$ Amylase ${ }^{12}$ & $6.2 \pm 0.6$ & $9 \pm 0.7$ & $6.71 \pm 0.51$ & $9.1 \pm 0.35$ \\
\hline
\end{tabular}

(Units : Iu/ $1^{1-6}, \mathrm{mg} / \mathrm{dl}^{7-9}, \mathrm{U} / \mathrm{1}^{10,11,} \mathrm{IU} / \mathrm{l}^{12}$,

t values : diabetics vs non-diabetics, $\mathrm{p}=<0.01$ highly significant $*$ ) 